\title{
Diet and milk secretion in the sow
}

\section{By J. A. F. Rook and R. C. WITTER, Division of Agricultural Chemistry, School of Agricultural Sciences, University of Leeds}

Information on the effect of diet on milk secretion in the sow is limited. Sow's milk lacks the commercial interest of cow's milk, and experimental studies of milk secretion are inherently more difficult to conduct in the sow than in the cow. The sow does not voluntarily eject milk in response to stimuli other than those provided by the suckling pig, and manual or mechanical removal of milk from the udder is obstructed. Braude, Coates, Henry, Kon, Rowland, Thompson \& Walker (1947) introduced a technique of intravenous injection of oxytocin into an ear vein to induce milk ejection and to permit manual removal of the milk, and this approach has since been used extensively in conjunction with mechanical removal of the milk by machine (Lodge, I957; Salmon-Legagneur, 1959; Smith, 1959a; Hartman \& Pond, I960). Using this technique, a sample of milk suitable for analysis may readily be obtained but, for meaningful measurements of milk yield, a routine of weighing piglets before and after suckling, over a period of $12-24 \mathrm{~h}$ and with suckling intervals of not more than about $\mathrm{r} h$, has to be adopted.

\section{Yield and composition of sow's milk}

The yield of milk by the sow is dependent on litter size (Bonsma, 1935) but for a typical 8-week lactation on average the total yield is of the order of $300-400 \mathrm{~kg}$. Lodge (1958) reported an average daily yield of $8 \cdot \mathrm{I} \mathrm{kg}$ for measurements made over a total of twenty-four lactations with eight sows; the average yield in the ist week was $6.8 \mathrm{~kg} /$ day and the peak yield, in the 3 rd week of lactation, was $9.5 \mathrm{~kg} /$ day. The peak in yield usually occurs between the 3 rd and 5 th weeks of lactation.

Sow's milk is richer than cow's milk in all major constituents and more particularly in protein and fat. Some of the average values reported in the literature are given in Table I. Casein and $\beta$-lactoglobulin account for smaller proportions (about $55 \%$ and $2 \%$ respectively) and globulin for a higher proportion (10-1 $7 \%$ ) of total protein in sow's milk than in cow's milk (Sheffy, Shahani, Grummer, Phillips \& Sommer, 1952; Salmon-Legagneur, 1965 ). There is some discrepancy in the values reported for $\alpha$-lactalbumin and for proteose-peptones in sow's milk.

There are marked lactational trends in composition. Protein content falls rapidly within the first $24 \mathrm{~h}$ after farrowing, and then more slowly until the end of the Ist week. During the same period the percentages of ash, lactose and fat rise. Throughout the rest of the lactation, the contents of protein and of ash tend to rise and of lactose and fat to fall (see Lucas \& Lodge, 196r). Fat content, however, fluctuates widely: day-to-day variations of up to $30 \%$ have been observed, whereas the corresponding variations in lactose and protein were of the order of $15 \%$ (Perrin, 1954). Differences between teats in the fat content of milk have been reported (Smith, I952), but this was not confirmed by Jylling \& Sørensen (1960) nor by Duncan \& Garton (1966). 
Table I. Average values for the composition of milk of the sow

\begin{tabular}{|c|c|c|c|c|c|c|c|c|}
\hline $\begin{array}{l}\text { No. of } \\
\text { sows }\end{array}$ & $\begin{array}{c}\text { No. of } \\
\text { samples } \\
\text { analysed }\end{array}$ & $\begin{array}{l}\text { Total } \\
\text { solids } \\
(\%)\end{array}$ & $\begin{array}{l}\text { Fat } \\
(\%)\end{array}$ & $\begin{array}{l}\text { Solids- } \\
\text { not-fat } \\
(\%)\end{array}$ & $\begin{array}{c}\text { Protein } \\
(\%)\end{array}$ & $\begin{array}{c}\text { Lactose } \\
(\%)\end{array}$ & $\begin{array}{l}\text { Ash } \\
(\%)\end{array}$ & Reference \\
\hline $\begin{array}{r}9 \\
20\end{array}$ & $\begin{array}{l}40-76 \\
32-67\end{array}$ & $\begin{array}{l}19.87 \\
20.08\end{array}$ & $\begin{array}{l}8.17 \\
6.81\end{array}$ & $\begin{array}{l}\mathrm{I} \cdot 67 \\
\mathrm{I} 3 \cdot 27\end{array}$ & $\begin{array}{l}5 \cdot 79 \\
7 \cdot 26\end{array}$ & $\begin{array}{l}4 \cdot 8 \mathrm{I} \\
5 \cdot 12\end{array}$ & $\begin{array}{l}0.94 \\
0.99\end{array}$ & $\begin{array}{l}\text { Braude et al. (1947) } \\
\text { Bowland, Grummer, } \\
\text { Phillips \& Rohstedt } \\
\text { (1949) }\end{array}$ \\
\hline 44 & $\begin{array}{l}>45^{\circ} \\
1,500\end{array}$ & $\begin{array}{l}21 \cdot 23 \\
18 \cdot 40\end{array}$ & $\begin{array}{l}9 \cdot 5^{8} \\
6 \cdot 17\end{array}$ & $\begin{array}{l}\text { II } 65 \\
12 \cdot 23\end{array}$ & $\begin{array}{l}6 . \text { I I } \\
5.83\end{array}$ & $\begin{array}{l}4 \cdot 62 \\
5 \cdot 42\end{array}$ & $\begin{array}{l}0.92 \\
0.92\end{array}$ & $\begin{array}{l}\text { Perrin (I954) } \\
\text { Salmon-Legagneur } \\
\text { (I965) }\end{array}$ \\
\hline
\end{tabular}

Fat content may vary erratically throughout a milking, more particularly early in lactation (Perrin, 1954), and there is not the progressive increase in fat content observed in the cow (Jylling \& Sørensen, 1960; Whittlestone, 1952).

The fatty acids of sow's milk fat consist mainly (about $90 \%$ on a w/w basis) of acids with sixteen or eighteen carbon atoms. The average proportions $(w / w)$ of the principal fatty acids of the milk fat of sows given diets having a high content of barley, as calculated from the results of Lindberg \& Tollerz ( 1964$)$ and of Duncan \& Garton (1966), are: myristic acid, $4 \%$; palmitic acid, 36\%; palmitoleic acid, $12 \%$; stearic acid, $4 \%$; oleic acid, $32 \%$; linoleic acid, $9 \%$. An absence of short- and branchedchain acids and a high content of palmitoleic acid distinguish sow's milk fat from the milk fat of ruminants. Colostral fat in the sow is richer in oleic and linoleic acids and lower in palmitic and palmitoleic acids than milk fat. Day-to-day variations in oleic and palmitic acid contents of the milk fat are marked; Lindberg \& Tollerz (1964) have suggested that they might reflect variations in the extent to which the milk fat is derived from plasma triglycerides and from synthesis de novo from 2carbon units. The positional distribution of fatty acids on the glycerol molecule is the same as in pig depot fat, with palmitic acid located preferentially in the 2position and stearic acid and the $\mathrm{C}_{18}$ unsaturated acids in the I- and 3-positions of the glycerol molecule (Duncan \& Garton, ig66).

\section{Effects of diet on milk yield and composition}

Plane of energy nutrition. Observations on the effect of plane of energy nutrition of the sow on the yield and composition of her milk are summarized in Table 2. In all but two of the experiments comparisons were made, not within animals, but between groups of three to eight pigs at different levels of nutrition, and errors attached to observed differences inevitably are large. There is, nevertheless, a considerable consistency between the results of the various investigations.

Yield of milk is clearly dependent on the plane of energy nutrition during lactation, irrespective of the level of feeding during pregnancy. The fall in yield with energy undernutrition is associated with a decrease in lactose content and an increase in the contents of fat and ash, and with the exception of one experiment, in protein also. In terms of the yields of the various constituents, however, only the yield of ash is unaffected by energy undernutrition; the yields of fat, protein and 
Table 2. Summary of results of investigations on the effect of energy over-or undernutrition in the sow on the yield and composition of her milk

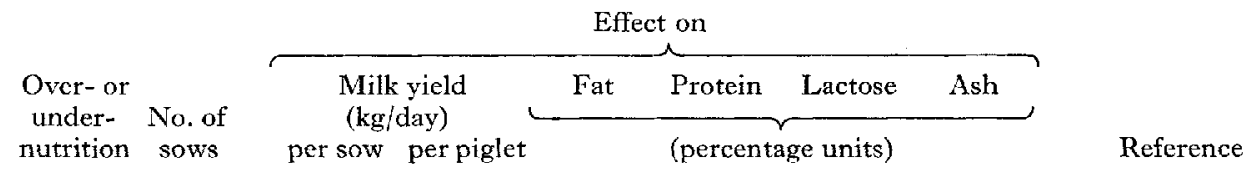

(a) Over- or under-nutrition during lactation; normal feeding during pregnancy

\begin{tabular}{|c|c|c|c|c|c|c|c|c|}
\hline$+30 \% t$ & 10 & +1.01 & - & - & 一 & - & - & $\begin{array}{l}\text { Salmon-Legagneur } \\
\text { (1965) }\end{array}$ \\
\hline$-20 \%$ & 20 & +0.02 & 一 & \pm 0.0 & -0.1 & -0.1 & 10.0 & $\begin{array}{l}\text { Salmon-Legagncur } \\
\left(\operatorname{Ig}_{5}\right)\end{array}$ \\
\hline$-30 \%+$ & 14 & -0.64 & — & +0.2 & +0.3 & -0.2 & to.I & $\begin{array}{l}\text { Salmon-Legagncur } \\
\text { (I965) }\end{array}$ \\
\hline$-33 \%$ & 10 & -0.64 & -0.05 & +0.3 & $+0 . r$ & -0.2 & 一 & Smith (r959b) \\
\hline$-35 \%$ & $8 \pm$ & $-I \cdot 40^{*}$ & - & +0.89 & $+0.5 I^{*}$ & $-0 \cdot 32$ & $+0.07 *$ & Lodge (I959b) \\
\hline$-50 \%$ & $\times 6$ & $-I \cdot 36$ & - & $\div 0.4$ & +0.3 & -0.1 & - & $\begin{array}{l}\text { Salmon-Legagneur } \\
\text { (1965) }\end{array}$ \\
\hline From & & & & & & & & \\
\hline $\begin{array}{l}-33 \% \\
-50 \%\end{array}$ & 9 & -0.44 & 44 & 0.3 & 0.2 & -0.14 & - & Smith (1959b) \\
\hline
\end{tabular}

(b) §Undernutrition during lactation; underfeeding during pregnancy

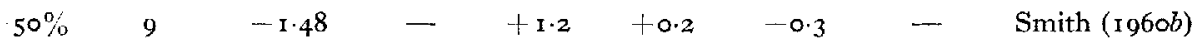

(c) Undernutrition during lactation and last month of pregnancy

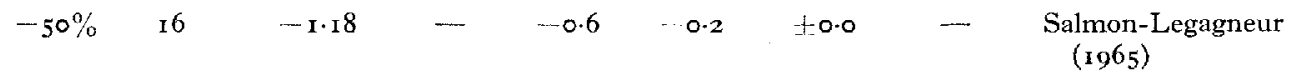

(d) Undernutrition during last month of pregnancy; normal feeding during lactation

$\begin{array}{llllllll}-50 \% & 16 & -0.68 & -0.9 & +0.4 & -0.1 & -0.0 & \begin{array}{l}\text { Salmon-Legagneur } \\ \text { (ig65) }\end{array}\end{array}$

(e) Undernutrition during pregnancy; underfeeding during lactation

$\begin{array}{lcccccccl}-25 \% & 8 & -1.39 & -0.04 & -0.90 & +0.30 & +0.0 & \cdots & \text { Smith (1960b)\$ } \\ -27 \% & 10 & \pm 0.0 & -0.10 & -0.06 & -0.18 & \pm 0.0 & - & \text { Smith (1960a) } \\ -50 \% & 16 & +0.01 & - & -1.00 & -0.50 & -1.0 & - & \text { Salmon-Legagneur } \\ \text { (Ig65) }\end{array}$

$* P<0.05$.

+Within-animal comparisons; all other comparisons made between animals.

†Replicated over three successive lactations.

$\$$ After undernutrition over the full previous reproductive cycle.

|IDuring last month of pregnancy only.

lactose all are depressed but that of lactose to the greatest extent (Fig. I). Undernutrition throughout pregnancy and lactation has a similar effect on yield and composition, except that the depression in fat yield is more marked and milk fat content is reduced.

Energy undernutrition in pregnancy has, in some experiments, depressed milk yield, but lactose content was not then affected and fat content was decreased; results for protein content were variable. In all experiments, the yields of fat and, to a lesser extent, of protein were decreased but the yield of lactose either was unaffected or was only slightly reduced. 


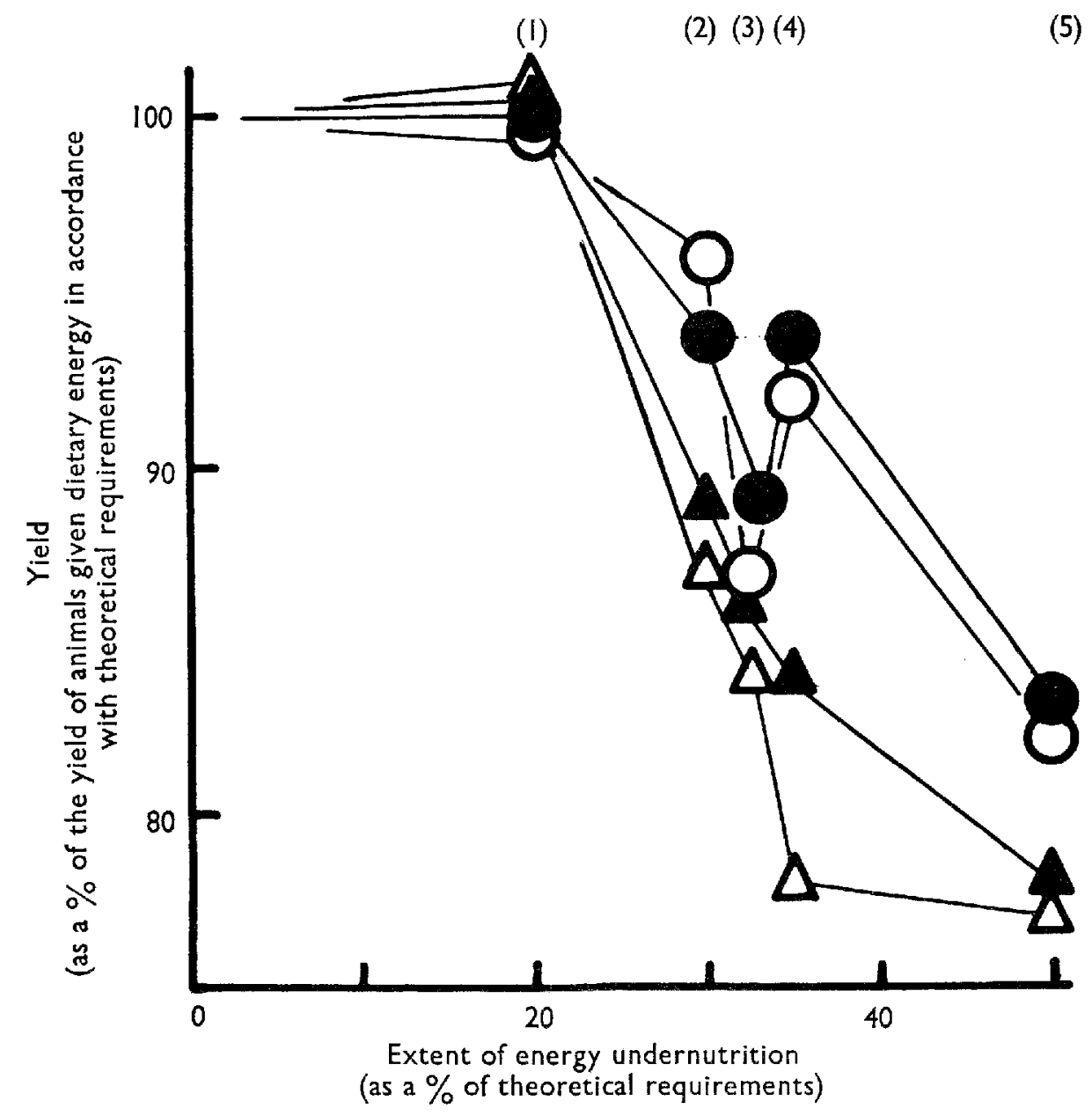

Fig. I. Effect in the sow of encrgy undernutrition during lactation (normal feeding during pregnancy) on the yields of milk $(\mathbf{\Delta})$, fat $(\Theta)$, lactose $(\triangle)$ and protein $(O) .(1,2,5$, Salmon-Iegagneur $(1965)$; 3. Smith $(1959 b) ; 4$, Lodge $(1959 b)$.)

In none of the above experiments were effects on the contents of individual milk proteins or on the fatty acid composition of milk fat determined. Tollerz \& Lindberg $\left(1^{6} 5_{5}\right)$ have found starvation of a sow for $30 \mathrm{~h}$ to increase the proportion of $\mathrm{C}_{18}$ acids and to decrease that of the $\mathrm{C}_{16}$ acids.

Quantity and quality of dietary protein. No clear-cut effect of either the quantity or quality of dietary protein on milk yield or composition has been established. Lodge (1959a), in a comparison of three levels of dietary protein, observed decreases in milk yield and in milk nitrogen content with increases in the amount of dietary protein, but the effects were not statistically significant. Salmon-Legagneur (1965) investigated the effects of high-protein diets during pregnancy and lactation. Increasing the intake of dietary protein during the last month of pregnancy to $125 \%$ of theoretical requirements was without significant effect on milk yield or nitrogen 
content. An increase in dietary protein to $30 \%$ above the needs for lactation had no effect on the yield or on the concentrations of the major milk constituents, but the milk content of $\alpha$-lactalbumin was significantly increased.

The replacement of fish meal by groundnut meal during gestation has been reported (Salmon-Legagneur, 1965) to be without effect on milk protein content but, in the second of two successive lactations during which the groundnut meal was given, milk yield was depressed. Addition of animal proteins in the form of tankage or fish solubles, to a ration of maize meal, soya-bean meal and alfalfa had no effect on total protein or casein contents of milk (Sheffy et al. 1952). Smith (1959a), however, observed an improvement in milk yield in response to the replacement of a concentrate mixture of barley and meat protein by separated milk.

Amount and composition of dietary fat. An effect of the amount and type of dietary fat on the yield and composition of milk fat is well established (Willett \& Maruyama, 1946; Norman, Sheffy \& Willman, 1955). The most detailed and systematic study has been made by Salmon-Legagneur (1965). In a first experiment, lard either (a) as a simple addition, (b) together with fish meal to maintain the nitrogen to calorie ratio, or (c) as a replacement for an isocaloric amount of basal diet, was added to a low-fat diet to give a fat content of $17 \%$. The inclusion of lard invariably increased fat content, the mean increase for each of the treatments being 0.7 , I. I and I.I percentage units, and treatment (a) also increased milk yield. The composition of milk fat also was altered, the proportion of saturated acids being decreased and of unsaturated acids (palmitoleic, oleic, linoelic and arachidonic) increased, even though the lard was more saturated than the milk fat secreted by animals on the basal, low-fat diet.

In a second experiment, addition of maize oil (containing about $45 \%$ linoleic acid) to a low-fat diet was made either during pregnancy or during lactation. An increase in fat content was observed only with the addition during lactation. The milk fat composition was altered by both treatments, but the effect was more marked with the addition during lactation. Linoleic acid content was increased, mainly at the expense of the saturated acids but also to a more limited extent of oleic and palmitoleic acids. Depot fat increased in linoleic acid content when maize oil was given during pregnancy but not when given during lactation. The inclusion of coconut oil rich in lauric acid and, to a lesser extent, myristic acid, was shown in a later experiment to have a similar, though less marked effect. Increases in the lauric and myristic acid contents of milk fat occurred at the expense of oleic and to a limited extent of palmitic and palmitoleic acids, but the increase in the yield of fat when coconut oil was given during lactation was almost quantitatively accounted for by an increased secretion of lauric and myristic acids.

The findings of Salmon-I egagneur have been amply confirmed by other workers. Increases in milk fat content have been observed by Asplund (1960) and de Man \& Bowland $\left(\mathrm{I} g 6_{3}\right)$ in response to the addition of tallow to the diet during lactation. Increases in milk fat of the major acid of the dietary fat have been observed during the feeding of linseed oil (rich in linolenic acid) and of cottonseed oil (rich in linoleic acid) (Tollerz \& Lindberg, 1965; Witter \& Rook, unpublished). Rapeseed oil, rich 
in erucic acid, however, gives no increase in the erucic acid content of milk fat (Witter \& Rook, unpublished).

Dietary fat has a more profound effect on the composition of the blood plasma trigylcerides than on the triglycerides of milk (Witter \& Rook, unpublished) and it appears that the changes in composition of the milk triglycerides are mediated through changes in the fatty acids of the plasma triglycerides. During lactation, dietary fat composition is without effect on the composition of depot fat; there is apparently a preferential use of fatty acids of dietary origin for milk fat synthesis (Salmon-Legagneur, 1965). The composition of depot fat is, however, affected by the composition of dietary fat during pregnancy (Salmon-Legagneur, 1965) and mobilization of depot fat during lactation presumably influences the amount and composition of the plasma triglycerides and hence the amount and composition of milk fat.

There is no information on the effect of diet on the synthesis de novo of fatty acids within the udder.

One of us (R.C.W.) is in receipt of a grant from the Pig Industry Development Authority.

\section{REFERENCES}

Asplund, J. MI. (1960). Diss. Abstr. 20, 391 1,

Braude, R., Coates, M. E., Henry, K. M., Kon, S. K., Rowland, S. J., Thompson, S. Y. \& Walker, D. M. (1947). Br. F. Nutr. I, 64 .

Bonsma, F. N. (1935). S. Afr. J. Sci. 32, 360.

Bowland, J. P., Grummer, R. H., Phillips, P. H. \& Bohstedt, G. (I949). J. Dairy Sci. 32, 22.

de Man, J. M. \& Bowland, J. P. (r963). I. Dairy Res. 3o, 339.

Duncan, W. R. H. \& Garton, G. A. (1966). F. Dairy Res, 33, 255.

Hartman, D. A. \& Pond, W. G. (1960). F. Anim. Sci. 19, 780 .

Jylling, B. \& Sørensen, P. H. (1960). Arsskr. K. Vet.-Landbohøjsk. p.2o.

Lindberg, P. \& Tollerz, G. (1964). Acta vet. scand. 5, 311.

Lodge, G. A. (1957). F. agric. Sci, Camb. 49, 127.

Lodge, G. A. (1958). PhD Thesis, University of Aberdeen.

Lodge, G. A. (1959a). F. agric. Sci., Camb. 53, r 72 .

Lodge, G. A. (1959b). 7. agric. Sci., Camb. 53, $\times 77$.

Lucas, I. A. M. \& Lodge, G. A. (1961). Tech. Commun. Commonw. Bur. Anim. Nutr. no. 22.

Norman, R., Sheffy, B. E. \& Willman, J. P. (1955). F. Anim. Sci. 14, 1219.

Perrin, D. R. (1954). F. Dairy Res. 21, 55.

Salmon-Legagneur, E. (1959). Annls Zootech. 8, 93.

Salmon-Legagneur, E. (1965). Annls Zootech. 14, No. Hors-série I.

Sheffy, B. E., Shahani, K. M., Grummer, R. H., Phillips, P. H. \& Sommer, H. H. (I952). F. Nutr. 48, то3.

Smith, D. M. (1952). Proc. N.Z. Soc. Anim. Prod. 12, roz.

Smith, D. M. (1959a). N.Z. Yl agric. Res. 2, 1057.

Smith, D. M. (1959b). N.Z. Yl agric. Res. 2, 1071.

Smith, D. M. (1960a). N.Z. Fl agric. Res. 3, 598.

Smith, D. M. (1960b). N.Z. Fl agric. Res. 3, 745 .

Tollerz, G. \& Lindberg, P. (1965). Acta vet. scand. 6, I18.

Whittlestonc, W. G. (1952). If. Dairy Res. 19, I 27.

Willett, E. L. \& Maruyama, C. (I946). \%. Anim. Sci. 5, 365. 